TITLE:

\title{
Effect of physical state on pain mediated through emotional health in rheumatoid arthritis(Abstract_要旨)
}

AUTHOR(S):

Nakagami, Yukako

\section{CITATION:}

Nakagami, Yukako. Effect of physical state on pain mediated through emotional health in rheumatoid arthritis. 京都大学, 2019, 博士(医学)

ISSUE DATE:

2019-03-25

URL:

https://doi.org/10.14989/doctor.k21630

RIGHT:

許諾条件により本文は2019-10-01に公開; Final publication is available at the website of "Arthritis care and Research". 


\begin{tabular}{|l|l|c|c|}
\hline 京都大学 & 博士 (医学) & 氏 名 & 中 神 由 香子 \\
\hline & \multicolumn{2}{|c|}{ Effect of physical state on pain mediated through emotional health in } \\
詥文題目
\end{tabular}

論文題目 (関節リウマチ患者の身体的状態が精神的健康を媒介し疼痛へ与える影響)

\section{(論文内容の要旨)}

【背景】関節リウマチ患者の主たる訴えの一つとして疼痛があげられる。関節リウマ チ患者における疼痛は関節破壊などの身体的状態に起因していることから、疼痛は関 節リウマチの疾患活動性を反映すると考えられている。一方で、精神的状態が疼痛に 影響を与えうるため、関節リウマチ患者における疼痛を評価する際には、身体的状態 だけではなく精神的健康を加味する必要がある。関節リウマチ患者の身体的状態およ び精神的健康が疼痛に及ぼす影響を評価した既存研究は存在する。しかし、これらの 研究では、身体的状態を定義する際に精神的健康の影響を受けやすい患者の主観的評 価が用いられているといった問題がある。そこで、本研究では、関節リウマチ患者の 身体的状態を精神的健康から独立した複数因子で定義した上で、身体的状態が精神的 健康を媒介し疼痛に及ぼす影響を定量化した。

【方法】KURAMA (Kyoto University Rheumatoid Arthritis Management

Alliance）コホートに参加した関節リウマチ患者、計 548 人を研究対象とした。構造 方程式モデリングを用いて、関節リウマチ患者において、1）身体的状態が精神的健 康へ与える影響、および、2）身体的状態と精神的健康が疼痛へ与える影響を定量化 した。身体的状態、精神的健康、および、疼痛は潜在変数とした。身体的状態につい ては、関節リウマチの臨床において汎用されている総合的活動性指標の計算式を参考 に、客観的な測定值である赤血球沈降速度 (ESR)、 $\mathrm{C}$ 反応性蛋白 (CRP) 值、腫脹関 節数を選び出した上で、関節破壊の指標とされるマトリックスメタロプロテイナーゼ -3 (MMP-3) 值を合わせて評価した。精神的健康については、Hospital Anxiety and Depression Scale (HADS) を用いて評価した。不安症状・うつ症状については、一 般的に使用されているカットオフ值を用いた（8-10 点：疑い possible、11 点以上： ほぼ確実 probable)。疼痛については、圧痛関節数と視覚的アナログスケールを用い て評価した。

【結果】不安症状は 18.7\%（疑い 10.4\%、ほぼ確実 8.3\%）うつ症状は $29.4 \%$ （疑い $17.3 \%$ 、ほぼ確実 $12.1 \%$ ）に認められた。精神的健康は、身体的状態に有意な影響を 受けていた $(\beta=0.21)$ 。疼痛は、身体的状態 $(\beta=0.54)$ および精神的健康 $(\beta=0.29)$ に有意な影響を受けていた。身体的状態が疼痛に与える影響は精神的健康に媒介さ れ、この媒介効果（ $\beta=0.06 ）$ が総合効果に占める割合は $10.2 \%$ あった。

【結論】関節リウマチ患者において不安症状およびうつ症状を認める者の割合の高さ が示された。また、関節リウマチ患者における疼痛は、身体的状態による直接効果だ けでなく、精神的健康の媒介効果によっても説明されることが明らかとなった。

【考察】関節リウマチの疾患活動性は総合的活動性指標で評価される。この総合的活 動性指標は、圧痛関節数などの疼痛に関連した要因を加味して算出されるため、不安 や抑うつなどを有する関節リウマチ患者群においては、疾患活動性が過大評価されて いる可能性がある。現在の治療ガイドラインは疾患活動性に基づいて方針が定められ ているため、この群に対して、過度な免疫学的な治療が選択されていることが懸念され る。同時に、向精神薬の投与や精神療法等の精神科的治療が有効であることが期待される。
（論文審査の結果の要旨）

【背景】関節リウマチ患者の主訴の一つに疼痛がある。疼痛は、身体的状態、 及び、精神的健康の影響を受ける。これらの影響を評価した先行研究はあるが 身体的状態の定義に精神的健康の影響を受けやすい患者の主観的評価が含まれ ている、といった問題があった。

【方法】計 548 人の関節リウマチ患者を対象に、1）身体的状態が精神的健康 へ与える影響、及び、2）身体的状態と精神的健康が疼痛へ与える影響を、構造 方程式モデリングを用いて定量化した。身体的状態、精神的健康、及び、疼痛 は潜在変数とした。身体的状態は精神的健康の影響を受けにくい項目で定義し た。

【結果】疼痛は身体的状態 $(\beta=0.54)$ 、及び、精神的健康 $(\beta=0.29)$ から有 意な影響を受けていた。身体的状態が疼痛に与える影響は精神的健康によって 媒介され、その媒介効果（ $\beta=0.06 ）$ と総合効果（ $\beta=0.60 ）$ の Ratio は 0.102 であった。

【考察】本研究によって、関節リウマチ患者における疼痛・身体的状態・精 神的健康の関連が定量化された。関節リウマチの疾患活動性スコアには、疼痛 に関連した主観的評価の項目が含まれている。疼痛と精神的健康が関連してい ると、疾患活動性スコアに精神症状まで含めて評価している可能性がある。そ の場合には、免疫学的治療に加えて精神医学的治療を行うことが有効かもしれ ない。

以上の研究は、関節リウマチ患者の疼痛・身体的状態・精神的健康の関係性 を評価し、関節リウマチの臨床に寄与寸るところが多い。

したがって、本論文は博士（医学）の学位論文として価値あるもの と認める。

なお、本学位授与申請者は、平成 30 年 12 月 27 日実施の論文内容とそ れに関連した試問を受け、合格と認められたものである。

要旨公開可能日： 1 年 $\quad$ 月 $\quad$ 以降 